\title{
Political Security in Ethiopia: Situations and Legal Contests
}

\author{
Yayew Genet Chekol \\ Lecture, political science, Department of Civics and Ethics studies, college of social science, Salale University, \\ Fiche, Ethiopia
}

\begin{abstract}
s
Political security is the main integral component of human security and which is referring to the prevention of government repression, systematic violation of human rights and threats from militarization. Ethiopia has endorsed human rights from UDHR and by its FDRE, (1995) constitution in which such rights are accounts one third of the contents of the constitutions. The paper was aimed at examining the situations of political security and its challenge from legal perspective. It was investigated through qualitative research approach, secondary sources of data were highly employed, the time framed focused since 2005. According to the finding of the research the political security situations of Ethiopia characterized by torture and ill-treatment, political repression and enforced disappearances which are made by legal and institutional mechanisms by declaring different proclamations like Antiterrorism proclamation (ATP), Mass Media Proclamation (MMP), and Charity and Society proclamation (CSP) which are highly prohibiting the civil liberties and political rights of citizens' of Ethiopia.
\end{abstract}

Keywords: Political security, torture, political repression, disappearance

DOI: $10.7176 / \mathrm{IAGS} / 72-01$

Publication date:May $31^{\text {st }} 2019$

\section{Introduction}

The foremost concept of security, conventionally, was state centric, encompassing support and lawfulness to instruments of states and protecting the principle of state sovereignty. Plato's Ideal state, Aristotle's Statesman, Hobbs 'concept of Leviathan, Machiavelli's Prince and above all Marxian concept of Dictatorship of the proletariat highlight the ultimate goal or end of state as security and protection of individual and community, even though they have different views about the means to attain this goal. ${ }^{1}$ However; neither of these theories provided an independent identity and presence to human security nor did they cultivate conceptual framework on human security. Instead security was comprehended as fundamental part of national security which put emphasis on military centric solutions to security related issues. ${ }^{2}$

Traditional concepts of security emphasis on the territorial sovereignty of the state and its vital national interests, human security recognizes that the state has not always been able to assure the protection of its citizens and sometimes has been the perpetrator of insecurity and genocide. ${ }^{3}$

The concept of security has for too stretched been understood narrowly: as security of territory from external aggression, or as protection of national interests in foreign policy or as global security from the threat of a nuclear holocaust. It has been related more to nation-states than to people who sought security in their daily lives. For many of them, security symbolizes protection from the threat of disease, hunger, unemployment, crime, social conflict, political repression and environmental hazards. ${ }^{4}$

\section{Concepts of Human security}

Since the 1975, discussion of human security has begun to incorporate insights from the peace and disarmament debate, assessments of the impact of demographic change, and critiques of economic development. Conceptualization of security has therefore moved beyond preoccupation with the territorial integrity of nation states, and has been reinvigorated by the recognition that concerns for the individual - such as human rights, gender equity and a minimum social entitlement - have much to contribute to our understanding. In the nuclear debate, for example, it has been argued that the stability and well-being of communities and nations rests as much on factors associated with human development, economic growth, and democracy as on acquisition of a weapons arsenal. ${ }^{5}$

The primary goal behind the concept of human security, therefore, is the need to restore the security of people. Moreover, it refers to the premise that the prime objective of security is the safety and wellbeing of individual. Human security is both "human centered" and "security oriented". It is human centered in the sense

\footnotetext{
${ }^{1}$ Venu Menon, Sudha ,2007,Human security: Concept and practice, ICFAI Business School ,31 March

${ }^{2} \mathrm{Ibid}$

${ }^{3}$ Michael G. Smith and Jacqueline Whelan, 2008 Advancing Human Security: New Strategic Thinking For Australia, Security Challenges,

Vol. 4, No. 2. pp. 1-22.

${ }^{4}$ Jennifer Leaning, M.D., S.M.H. Sam Arie, M.Sc. 2001 Human Security: A Framework For Assessment In Conflict And Transition

Working Paper Series Volume 11 Number 8 September

${ }^{5}$ Ibid
} 
that it focuses on people both as individual and as group of individuals or communities; and it is security oriented because its emphasis is on freedom from fear. ${ }^{1}$

Human security goes beyond conventional paradigm of security in more ways than one. For conventional paradigm, security is regarded as the protection of state's vital interests and core values from external threats. Whereas human security describes security as individual's personal protection and preservation, which materializes not just from safeguarding of the state as a political unit, but also from the protection against structural violence that often accompanies many aspects of non-territorial threats. Evidently, this perspective on security widens and deepens the instruments and threats to security. ${ }^{2}$

Human security comprises several key elements: ${ }^{3}(1)$ the possibility for all citizens to live in peace and security in their own borders. This implies the capacity of states and citizens to prevent and resolve conflicts through peaceful and nonviolent means and, after the conflict is over, the ability to carry out reconciliation efforts.(2) People should enjoy without discrimination all rights and obligations-including human, political, social, economic and cultural rights. (3) Social inclusion - or having equal access to the political, (4) social and economic policy making processes, as well as to draw equal benefits from them. (5)Finally, the establishment of Commission on Human Security rule of law and the independence of the justice system. Each individual in a society should have the same rights and obligations and be subject to the same set of rules. ${ }^{4}$

Human security has five fundamental principles that differentiate it from simply working together. These are: People-centered, Comprehensive, Context-specific, Prevention-oriented, Protection and empowerment. ${ }^{5}$ Understanding of the serious and widespread threats facing human security can be deepened by placing them into seven di erent components, which UNDP defines in its 1994 Human Development Report 7

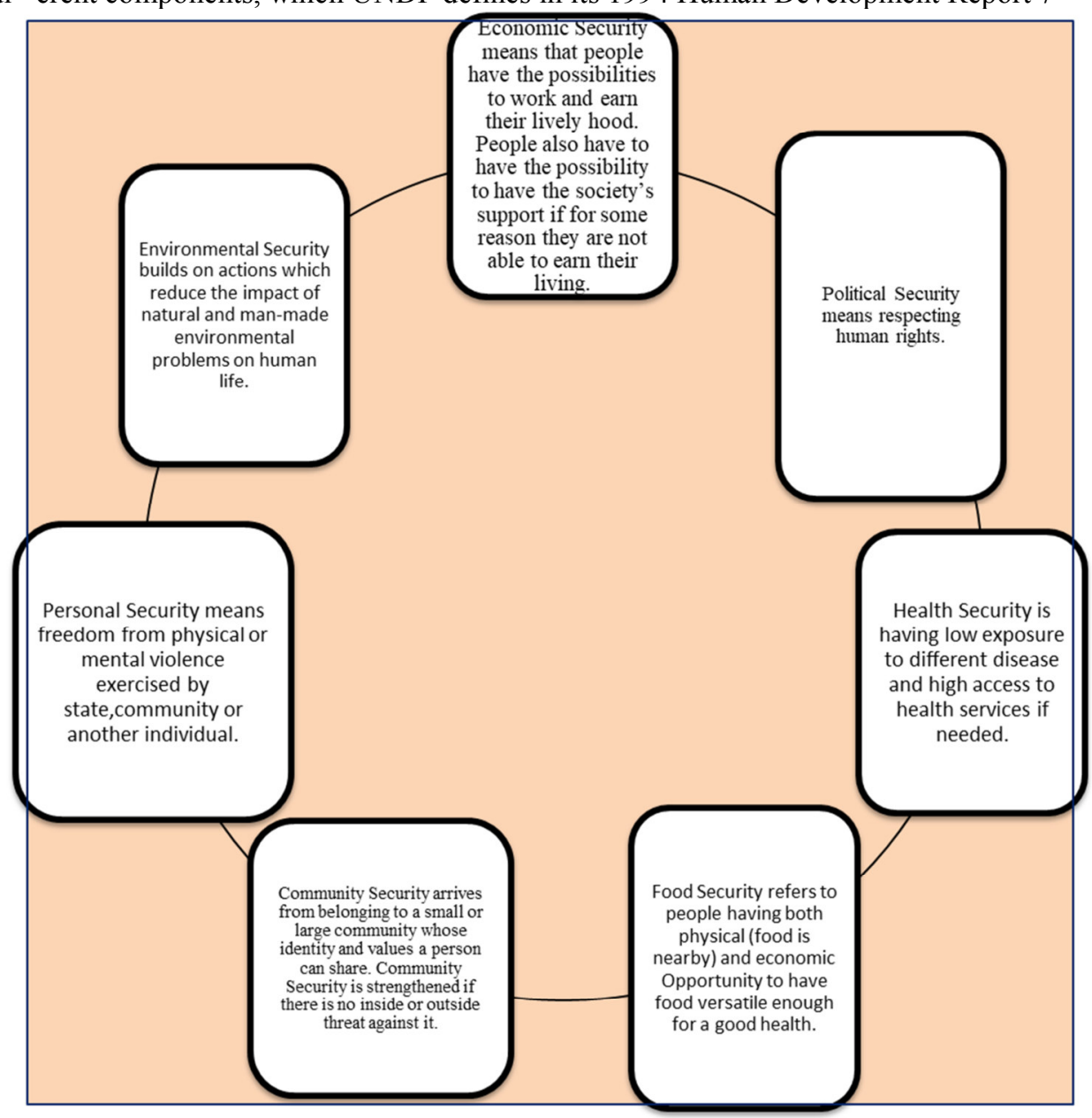

Diagram 1 Components of human security ${ }^{6}$

\footnotetext{
${ }^{1}$ Ramshe Thaker ,2011,the United Nations and human security ,Canadian Foreign policy Journal

${ }^{2}$ Sadako Ogata and Johan Cels, Human Security_-Protecting and Empowering the People ,Global Governance Vol. 9, No. 3 (July-Sept. 2003), pp. 273-282

${ }^{7}$ Haq, Mahbub ul (1995). Reflections on Human Development. p.115

${ }^{5}$ Source : united nation trust fund for human security ,2016, human security hand book

${ }^{6}$ Adapted from text in UNDP Human Development Report 1994: New dimensions of human security, pp. 25-33
} 
Types and causes of human insecurity ${ }^{1}$

\begin{tabular}{|l|l|}
\hline Types of human insecurities & Possible Root Causes \\
\hline Economic insecurity & $\begin{array}{l}\text { Persistent poverty, unemployment, lack of access to credit and other } \\
\text { economic opportunities }\end{array}$ \\
\hline Food insecurity & Hunger, famine, sudden rise in food prices \\
\hline Health insecurity & Epidemics, malnutrition, poor sanitation, lack of access to basic health care \\
\hline Environmental insecurity & Environmental degradation, resource depletion, natural disasters \\
\hline Personal insecurity & Physical violence in all its forms, human trafficking, child labuor \\
\hline Community insecurity & Inter-ethnic, religious and other identity-based tensions, crime, terrorism \\
\hline Political insecurity & Political repression, human rights violations, lack of rule of law and justice \\
\hline
\end{tabular}

\section{Political security}

In spite of the disagreement, human security is an important concept not to be ignored as a major discourse in contemporary debates about the world order. It gives worth the security field via it gives emphasis to human beings and incorporates non-military mechanisms as means to security. ${ }^{2}$ Human security is also related with social justice, human rights and human development. Scholars consider human security to be an idea that is component of the capability approach. Nussbaum explain capabilities as an important human entitlement, inherent in the idea of basic social justice, and can be viewed as one species of a human rights approach. ${ }^{3}$ For that reason, human security is closely related to human development and to human rights.

The concept include all aspects of human rights including the need for meeting basic needs and the demands of political and social freedom - both 'freedom from fear' and 'freedom from want'. People's interests or the interests of humanity, as a collective, is the focus of this approach. Thus, human security becomes an allencompassing condition in which individual citizens live in freedom, peace and safety that considered seriously. ${ }^{4}$

Political security one of the most important aspects of human security in which people should be able to live in a society that honours their basic human rights. In this respect, there has been considerable progress. The 1980s were in many ways a decade of democratic transition as many military dictatorships ceded power to civilian administrations and one- party states opened themselves up to multiparty elections. ${ }^{5}$

Moreover, political security defined as the prevention of government repression, systematic violation of human rights and threats from militarization. This was intended to establish an agenda that would protect people against states that continued to practice political repression, systematic torture, ill treatment and disappearance. ${ }^{6}$

Political security is concentrating on the protection of human rights protection from military dictatorships and abuse protection from political or state repression, torture, ill treatment, unlawful detention and imprisonment. ${ }^{7}$ Political security is the defense against any form of political oppression. It is concerned with whether people live in a society that honors their basic human rights. Extradition is a means of preserving political security. ${ }^{8}$

One of the most useful indicators of political insecurity in a country is the priority the government accords military strength since governments sometimes use armies to repress their own people. If a government is more concerned about its military establishment than its people, this imbalance shows up in the ratio of military to social spending. The two nations with the highest ratios of military spending to education and health spending in 1980 were Iraq ( 8 to 1$)$ and Somalia (5 to 1$){ }^{9}$

The International Covenant on Civil and Political Rights (ICCPR) is a treaty adopted by the United Nations in 1966 and agreed to subsequently by 169 countries that sets out a list of civil and political rights that we are all entitled to simply by virtue of being human. Civil and political human rights ensure individual ability to live, and to engage in religious, political, intellectual, or other activities free from coercion, abuse, or discrimination. ${ }^{10}$ Human Right measurement indicators (HRMI) metrics cover the following seven rights, each listed together with reference to the relevant article in the ICCPR or other core UN treaties further elaborating those rights, such as the International Convention for the Protection of all Persons from Enforced Disappearance and the Convention against Torture. (1) The right to be free from torture and ill-treatment (Article 7 and the Convention against Torture). (2) The right to be free from execution (Article 6 and the Second Optional Protocol to the ICCPR). (3)

\footnotetext{
${ }^{1}$ United Nation Trust Fund for Human Security, 2016, Human Security Hand Book

${ }^{2}$ Martha C. Nussbaum (2011). Capabilities, Entitlements, Rights: Supplementation and Critique. Pp.23-30.

${ }^{3}$ Ibid

${ }^{4}$ Thakur, Ramesh (1997). 'From National to Human Security’ Asia Pacific Security: The Economics-Politics Nexus.

5 UNDP,1994, human development report

$6 \mathrm{Oz}$ Hassan (2015) Political security: from the 1990s to the Arab Spring,

Contemporary Politics, 21:1, 86-99, DOI:

${ }^{7}$ United nation trust fund for human security, 2009, Human Security in Theory and Practice, united nations, USA

${ }^{8} \mathrm{Http} / /$ definition .us legal .com/political repression. Retrieved on February 18,2019

${ }^{9}$ UNDP, 1994, human development report, New York Oxford, Oxford University Press

${ }^{10}$ International Covenant on Civil and Political Rights. Adopted by the General Assembly of the United Nations on 19 December 1966
} 
The right to be free from arbitrary or political arrest and detention, (4) the right to be free from disappearance (Articles 9 and 10, and the Convention for the Protection of all Persons from Enforced Disappearance). (5) The right to political participation (Article 25), (6) the right to opinion and expression (Article 19), and (7) the rights to assembly (Article 21) and association (Article 22.) ${ }^{1}$ These indicators are closely related with political security of the citizen of a state such conventional rights are adopted by Ethiopian constitution.

\section{Legal frame works and practices of political security in Ethiopia 1931 constitution}

The 1931 constitution was not initiated by the demand of the people and it was not also initiated for the people. ${ }^{2}$ That is why there was no attention to guarantee popular sovereignty, political freedoms and fundamental human rights to the Ethiopian people. And the people were considered as subjects as they used to be, without granting any kind of political and civil rights. In general the constitution was formulated/ introduced mainly to attain two basic purposes that would advance the Emperor's authority and political control. This constitution served the interests of the Emperor. Thus, the 1931 constitution can be referred as the Charter of the absolute power of the monarchy. The political and human rights, freedoms and liberties of peoples of Ethiopia were denied.

\section{The 1955 revised constitution}

The 1955 revised constitution made the powers and authority of the Emperor absolute and complete in the Ethiopian state and society. In contrast, little significance was attached to the need to guarantee political and human rights of the Ethiopian people through protecting individual rights in terms of property, life and private affairs. ${ }^{3}$ However, in practice the mechanisms for implementing these limited rights were largely absent. There were no effective means for representing and reflecting the needs and interests of the people in the government. In the practical sense, Ethiopian people were still considered as merely subjects of the Emperor. Although the revised constitution of 1955 was a step forward in the history of constitutional development in Ethiopia, in effect it failed to lay down a democratic tradition in the Ethiopian political process.

In the end, it is possible to identify some progressive elements, which were included in the Revised Constitution of 1955. These were the following: (1) it gave at least textual recognition to rights and liberties of citizens, which included rights such as freedom of speech, freedom of press, freedom of assembly, and people's participation in election of the members of chamber of Deputies. But, there was no observance (enforcement) of these provisions of rights and freedoms of individuals in practice at all. It was only paper value to ordinary Ethiopians. (2) The Chamber of Deputies was made to have the power, at least in textual sense, to question the ministers with the view to hold the government accountable. ${ }^{4}$

\section{The 1987 PDRE constitution}

Matters pertaining to citizenship and fundamental freedom, rights and duties of citizens were given better coverage in the 1987 people democratic republic of Ethiopia (PDRE) constitution compared to the way they were treated under the previous constitutions ${ }^{5}$. To mention but few of the concerns, irrespective of their nationality, sex, religion, occupation, social or other status the constitution has provided that Ethiopians are equal before the law. This equality was to be manifested through equal participation in political, economic, social and cultural affairs. Moreover, the constitution came up with women's rights which until then had never been reflected in Ethiopian constitutions. It also set the duty to provide women with special support particularly in education, training, and employment so that they participate in political, economic, social, and cultural affairs on equal basis with men.

\section{The 1995 Constitution of FDRE}

It affirms that the peoples of Ethiopia are the source of sovereignty. It also explicitly states the rights and duties the two levels of governments i.et clearly declares the areas that purely fall under the jurisdiction of the federal government and regional governments as a well as their concurrent powers. ${ }^{6}$ It also states the political power shall be held through periodic, fair and free elections, which entitles the Ethiopian citizens to exercise their human, democratic, political, social and economic rights and freedoms. For this it recognizes and affirms fundamental human rights and freedoms in conformity with the United Nations Universal Declaration of Human Rights and other international human right instruments. ${ }^{7}$

The constitution dictates that any official or governmental body shall not exercise power arbitrarily. Officials and governments at all levels are to be held accountable to their people and responsible for their actions and decisions. If the people lose confidence on their elected representatives they have a constitutional right to

\footnotetext{
${ }^{1}$ ibid

${ }^{2} \mathrm{Http} /$ www.chilot. Ethiopian constitution of 1931, Addis Abeba 16. July

${ }^{3}$ Revised Constitution of the Empire of Ethiopia, Proclamation No. 149 of 1955

${ }^{4} \mathrm{Ibd}$

${ }^{5}$ The constitution of the peopl's Democratic Republic of Ethiopia,(1987),Negarit Gazetta,vol.47.no. 1,Addis Abeba,,12.September

${ }^{6}$ Federal Democratic Republic of Ethiopia Constitution, (1995). Negarit Gazeta, 1st Year Number.1, 1995.

ibid
} 
recall them at any time. ${ }^{1}$

\section{Materials and methods}

The paper was analyzed with the frameworks of qualitative research approach and followed case study design .It mainly focused on the political security of Ethiopia with in the last 27 years particularly since 2005 when high level of political turmoil was underway in post general national election. The paper includes the concepts of security and human security, and mainly focused on the essential components of human security specifically on political security which can be defined as the prevention of government systemic political repression, disappearance, torture and ill-treatment and it is the protection human right . The paper mainly examined the situation of political security and the legal instruments that made political insecurity in Ethiopia. The data sources of the paper are legal documents, different journals and reports of institutions were employed as a source.

\section{Discussions}

\subsection{Situation of political security in Ethiopia}

According to the data source that the researcher found torture and ill-treatment, political repression, disappearance continue to be major problems in Ethiopia. Ethiopian security personnel, including plainclothes security and intelligence officials, federal police, special police, and military, frequently tortured and otherwise ill-treated political detainees held in official and secret detention centers, to coerce confessions or the provision of information.

Former security personnel, including military, have described using torture as a technique to extract information. There are serious due process concerns and concerns about the independence of the judiciary on politically sensitive cases. Outside Addis Ababa, many detainees are not charged and are rarely taken to court. The researcher attempted to discuss each political security problem independently according to the data source.

\subsubsection{Torture and ill- treatment}

Article 18 of the FDRE Constitution provides that everyone has the right of protection against cruel, inhuman or degrading treatment or punishment and no one shall be held in slavery or servitude or be subject to human trafficking. ${ }^{2}$ The FDRE Criminal Justice Policy (2011) constitutes a key policy framework that seeks to promote citizens right to human dignity, security, liberty and the prohibition of torture and inhuman treatment.

Legislative measures have also been taken to protect citizen's right to Human Dignity, Security, and liberty which lay down the foundation for the protection from torture and inhuman treatment. These laws elucidate the basic concept of human dignity ${ }^{3}$ which is tied to inherent nature of the human person and the honor and respect to be accorded to human beings and protections offered to each person. ${ }^{4}$

Ethiopia ratified the United Nations Convention against Torture and Other Cruel, Inhuman or Degrading Treatment or Punishment in 2002 which now an integral part of the law of the land. In considering the issue of inhuman treatment and punishment in prisons, the government conducted focused investigations on whether there have been acts of torture against detainees. ${ }^{5}$

Although the constitution and law prohibit such practices, there were reports security officials tortured and otherwise abused detainees. Security force members beat detainees, including minors. Security force members used wooden sticks, rubber truncheons, and whips to do so. According to the report, several students stated they were hung by their wrists and whipped, four said they received electric shocks to their feet, and two had weights tied to their testicles. ${ }^{6}$

Mistreatment repeatedly occurred at Maekelawi, official detention centers, unofficial detention centers, police stations, and in Kilinto federal prison. There were reports police investigators used physical and psychological abuse to extract confessions in Maekelawi, the federal crime investigation center in Addis Ababa that often held high-profile political prisoners. Interrogators reportedly administered beatings and electric shocks to extract information and confessions from detainees.

Torture took place in local police stations, Maikelawi, federal police station, federal and regional prisons and military camps. Torture methods included: beating with sticks, rubber batons, gun butts and other objects; burning; tying in stress positions; electric shocks; and forced prolonged physical exercise. Some detention conditions amounted to torture, including detaining people underground without light, shackled and in prolonged solitary confinement.

Torture typically took place in the early stages of detention, in conjunction with the interrogation of the

\footnotetext{
${ }^{1}$ ibid

2 FDRE (1995) constitution

${ }^{3}$ Universal Declaration of Human Rights (UDHR): "Everyone has the right to life, liberty and security of person

${ }^{4}$ The FDRE Criminal Justice Policy (2011)

5 UN Universal Periodic Review (UPR) consideration of Ethiopia's human rights performance from 2009-14

${ }^{6}$ Human Right watch ,2018, Torture and other Abuses in Jail Ogaden, Somali Regional State, Ethiopia

${ }^{7}$ Country Reports on Human Rights Practices for 2016 United States Department of State • Bureau of Democracy, Human Rights and Labor.
} 
detainee. Torture was used to force detainees to confess, to sign incriminating evidence and to incriminate others. Those subjected to torture included prisoners of conscience, who were arrested for their perceived or actual expression of dissent. Defendants in several trials complained in court that they were tortured or otherwise illtreated in detention. The courts failed to order investigations into the complaints. In several cases, prisoners of conscience were denied access to adequate medical care. ${ }^{1}$

Types of tortures committed by government police and security force includes Torture Routines ,Beatings ,Rape and Other Sexual Violence, Genital Torture of Men , Water Torture ,Stress Positions ,Stripped Naked, Rolling in Hot Ash, Solitary Confinement and Room 8 , and Psychological Trauma and this evil acts committed particularly in Jigjiga ,Jail Ogaden ,Easter Ethiopia ${ }^{2}$

The use of various torture methods, which were almost exclusively used during interrogations. Several detainees explained that their physical mistreatment corresponded with their period of investigation, and often with their period of solitary confinement and detention in Dark House, in Amharic language which is termed as Chalama Bet. ${ }^{3}$ The torture methods are punching, slapping, and kicking ,beatings with objects (sticks, gun butts, electric wires), beating the victim on the soles of the feet with an object, Stress positions, including with hands and legs tied together, or standing up with hands tied up above head, Hanging the victim from the ceiling by the wrists by handcuffs so that the toes ,barely touch the ground, putting enormous pressure on the victim's wrists, Exposure to cold particularly by having cold water poured over the victim, which was often followed by whipping. ${ }^{4}$ Torture and ill-treatments are the usual activities of the security and police sectors of the state without considering the constitutional declared rights of the citizens.

\subsubsection{Political repression}

Political repression is the maltreatment of an individual or group for political reasons, especially for the purpose of limiting or forbidding their ability to take part in the political life of society. ${ }^{5}$ People were detained arbitrarily without charge for long periods in the initial stages, or throughout the duration, of their detention including numerous people arrested for peaceful opposition to the government or their imputed political opinion. Arbitrary detention took place in official and unofficial detention centers, including Maikelawi. Many detainees were held incommunicado, and many were denied access to lawyers and family members.

Numerous prisoners of conscience, imprisoned in previous years based solely on their peaceful exercise of their freedom of expression and opinion, including journalists and opposition political party members, remained in detention. These included some convicted in unfair trials, some whose trials continued, and some who continued to be detained without charge. Access to detention centers for monitoring and documenting the treatment of detainees continued to be severely restricted. ${ }^{6}$

The government has a record of monitoring, harassing, arresting, and detaining political opponents, journalists, human rights advocates, and other actual or perceived critics and their family members. Ethiopia had six federal prisons, 120 regional prisons, and many unofficial detention centers, including sites in Dedessa, Bir Sheleko, Tolay, Hormat, Blate, Tatek, Jijiga, Holeta, and Senkele. Pretrial detention often takes place in police stations, where prisoners endure unsanitary conditions and abuse. ${ }^{7}$ Lengthy legal procedures, large numbers of detainees, judicial inefficiency, and staffing shortages contribute to trial delays. The 2016-2017 and 2018 states of emergency allowed the government to detain a person without a court order. ${ }^{8}$

Arbitrary detention continued under the state of emergency declaration which was lifted in June. On 2 February, 2016 the government ordered the release of 10,000 of the 26,000 people arbitrarily detained and arrested, under the declaration, in 2016. Hundreds of people were detained under the ATP, which includes overly broad and vague definitions of terrorist acts punishable by up to 20 years' imprisonment. Detainees were held in excess of four months, the maximum period allowed under the law for pre-trial detention. ${ }^{9}$

The situation in Ethiopia has become increasingly unstable since security forces repeatedly fired upon protests in the Amhara and Oromia regions in August 2016. On 6 and 7 August2016 alone, based on the reports of Amnesty International at least 100 killings and scores of arrests during protests that took place across multiple towns in both regions. Protesters had taken to the streets throughout the Amhara and Oromia regions to express discontent over the ruling party's dominance in government affairs, the lack of rule of law, and grave human rights violations for which there has been no accountability. ${ }^{10}$

\footnotetext{
${ }^{1}$ Amnesty international report 2014/2015, The State Of The World's Human Rights

2 Human Right watch ,2018, Torture and other Abuses in Jail Ogaden, Somali Regional State, Ethiopia

${ }^{3}$ Human right watch ,2013, torture and ill treatment in Ethiopia's Maikelawi police station

${ }^{4}$ ibid

${ }^{5} \mathrm{Http} /$ definition .us legal .com/political repression. Retrieved on February 18,2019

${ }^{6}$ Human right watch ,2013, torture and ill treatment in Ethiopia's Maikelawi police station

${ }^{7}$ Center for International Human Rights Law \& Advocacy, 2018, Divide, Develop, and Rule: Human Rights Violations In Ethiopia, University of Wyoming College Of Law

${ }^{8}$ Ibid

${ }^{9}$ Amnesty international report 2017/2018, The State Of The World's Human Rights

${ }^{10}$ Association for Human Rights in Ethiopia,2016, Addressing the escalating human rights crisis in Ethiopia,Geneva
} 


\subsubsection{Disappearance}

No one shall be subjected to enforced disappearance. No exceptional circumstances what so ever, whether a state of war or a threat of war, internal political instability or any other public emergency, may be invoked as a justification for enforced disappearance. For the purposes of this Convention, "enforced disappearance" is considered to be the arrest, detention, abduction or any other form of deprivation of liberty by agents of the State or by persons or groups of persons acting with the authorization, support or acquiescence of the State, followed by a refusal to acknowledge the deprivation of liberty or by concealment of the fate or whereabouts of the disappeared person, which place such a person outside the protection of the law. ${ }^{1}$ This convention is ratified by Ethiopian incumbent government.

There were credible reports than in previous years of disappearances of civilians after clashes between security forces and rebel groups. Opposition parties reported disappearances of party members and observers before and after the national elections on May 24; 2010, however, the Ethiopian Human Right Commission (EHRC) later located some of those individuals. Many of those reported missing had fled to Kenya. Due to poor prison administration, family members reported missing individuals who were in custody of prison officials, but whom the families could not locate. ${ }^{2}$

Individuals repeatedly arrested by security forces as part of the government's response to protests disappeared. In a June report on the government's response to Oromo protests, HRW reported hundreds of persons were "unaccounted for" including children. Due to poor prison administration, family members reported individuals missing who were in custody of prison officials, but whom the families could not locate. ${ }^{3}$

Individuals, including children, arrested by security forces during the state of emergency ( SOE ) temporarily were held incommunicado. The government announced plans to disclose names of state of emergency (SOE) detainees in November 2016, but this effort was not comprehensive. Authorities used local government offices, colleges, training centers, and military training camps throughout the country as temporary detention centers. Due to poor prison administration, family members reported individuals missing who were in custody of prison officials, but whom the families could not locate. ${ }^{4}$

\subsection{Legal contests of political insecurity \\ 6.2.1 Anti-terrorism proclamation}

The government enacted the Anti-Terrorism Proclamation (ATP) in 2009, creating a broad definition of terrorism and expanding government powers toward terrorism suspects. ${ }^{5}$ In enacting the ATP, the government claimed that existing law was inadequate to combat the threat of terrorism and to meet Ethiopia's obligations under international law. ${ }^{6}$ The ATP defines "terrorist acts" to include acts causing serious bodily injury, serious risk to public health and safety, serious damage to property, or serious interference or disruption of any public service; if intended to "advance a political, religious or ideological cause by coercing the government, intimidating the public or section of the public, or destabilizing or destroying the fundamental political, constitutional or, economic or social institutions of the country.",

The law expands the powers of police and security services to survey, search, arrest, and detain terrorism suspects. ${ }^{8}$ It also relaxes evidentiary and procedural rules in terrorism cases, allowing courts to admit hearsay or indirect evidence and intelligence reports - even reports that do not identify how information was gathered or from whom. ${ }^{9}$ The ATP has received widespread condemnation..$^{10} \mathrm{UN}$ bodies, human rights organizations, and scholars have criticized the law's broad and vague definition of terrorism for including damage to property and disruption of public services. ${ }^{11}$ Political protests causing disruption to public transportation, for example, could be treated as acts of terrorism. ${ }^{12}$ Critics have also expressed concern that the ATP gives police and security services too much power to conduct warrantless searches and to seize property, authorizes detention of suspects for up to four months without charge, and places no prohibition on the use of evidence obtained through torture. $^{13}$

\footnotetext{
${ }^{1}$ Declaration on the Protection of All Persons from Enforced Disappearance adopted by the General Assembly of the United Nations in its resolution 47/133 of 18 December 1992 ,

${ }^{2}$ United States Department of State Country Reports on Human Rights Practices for 2015• Bureau of Democracy, Human Rights and Labor

${ }^{3}$ United States Department of State Country Reports on Human Rights Practices for 2016• Bureau of Democracy, Human Rights and Labor

${ }^{4}$ United States Department of State Country Reports on Human Rights Practices for 2016• Bureau of Democracy, Human Rights and Labor

${ }_{6}^{5}$ Anti-Terrorism Proclamation 652/2009 (July 7, 2009), http://www.refworld.org/docid/4ba799d32.html.

6 http://www.un.org/en/sc/ctc/specialmeetings/2012/docs/United Nations Security Council Resolution 1373 (2001).pdf (directing States to take measure to prevent and punish terrorism).

${ }^{7}$ Anti-Terrorism Proclamation, 652/2009 (July 7, 2009), Art. 3, http://www.refworld.org/docid/4ba799d32.html.

${ }^{8}$ Ibid Art,13-22

9 Ibid Art 23

${ }^{10}$ European Parliament, Resolution on the Situation in Ethiopia (January 21, 2016), 2016/2520(RSP),

${ }^{11}$ Mengesha, Silencing Dissent, 27 Journal of Democracy 93 (2016)

${ }^{12}$ Human Rights Watch, Analysis of Ethiopia's Draft Anti-Terrorism Law (June 30, 2009), https://www.hrw.org/print/237005.

${ }^{13}$ The Oakland Institute And The Environmental Defender Law Center, Ethiopia's Anti-Terrorism Law: A Tool To Stifle Dissent 14-17
} 
Moreover, since 2011, the government has used the ATP to charge political opponents, human rights advocates, teachers, students, journalists, and religious leaders and their supporters with acts of terrorism or affiliation with terrorist organizations. ${ }^{1}$

The Anti-Terrorism Proclamation (ATP) has also been used to silence political opposition and voices critical of government policy and practice. ${ }^{2}$ The Proclamation's provisions defining 'terrorist acts', 'moral support to terrorism and terrorist organizations', and 'search, seizure, detention and arrest' are vulnerable to abuse especially in a country not well known for judicial integrity. The Government of Ethiopia denies that the law was aimed at political opposition parties or journalists. Yet, journalists, political opposition leaders and dissidents, have been arrested, and convicted for alleged involvement and links to the three domestic organizations that the government considers to be terrorist groups - the Ogaden National Liberation Front (ONLF), the Oromo Liberation Front (OLF), and Ginbot-7. ${ }^{3}$ The ATP has been used against members and leaders of opposition political parties, journalists and human rights defenders since its enactment in 2009.

According to Ethio-Trial Tracker (ETT) an online project tracking prosecutions brought under the ATP as of mid-January 2018, 923 individuals were being prosecuted on terrorism-related charges. ${ }^{4}$ Among them, 440 $(48 \%)$ are alleged to have connections with the Oromo Liberation Front (OLF), and 311 (34\%) are alleged to have connections with Ginbot $7 .^{5}$ ETT has also documented an additional 526 individuals previously charged with terrorism. 463 were sentenced to prison or death; 63 were acquitted or had charges dropped. ${ }^{6}$

\subsubsection{Mass Media Proclamation}

The FDRE Constitution provides that everyone has the right to hold opinions and the right to freedom of expression without any interference. ${ }^{7}$ These rights are promoted in Ethiopia by enabling citizens to seek, receive and impart information and ideas of all kinds, regardless of frontiers, either orally, in writing or in print, in form of art, or through any media of one's choice. Freedom of the press and other mass media and freedom of artistic creativity, which is guaranteed in the constitution, is implemented through detailed legal instruments. ${ }^{8}$

The government has also created laws targeting independent media. Among the most controversial is the Freedom of Mass Media and Access to Information Proclamation (MMP). ${ }^{9}$ Enacted in 2008, the MMP requires publishers of periodicals 111 to register with the Ministry of Information latter now known as the Government Communications Affairs Office (GCAO) - gives public prosecutors and courts vague powers to block publication of books and periodicals, and creates stiff monetary penalties for defamation. Lawsuits have been brought against many independent newspapers under the MMP. ${ }^{10}$ The MMP recognizes a qualified right 115 of citizens to access information held by public bodies and creates a process for making access-to-information requests. In practice, however, the government makes information difficult if not impossible to obtain

\subsubsection{Charities and Society Proclamation}

In the wake of the 2005 elections, the government also created laws targeting opponents and civil society groups. Among the most controversial is the Proclamation to Provide for the Registration and Regulation of Charities and Societies, commonly referred to as the Charities and Societies Proclamation (CSP). Enacted in January 2009, the CSP imposes broad government oversight on civil society organizations. ${ }^{11}$ The government gave organizations a one-year grace period to conform to the new law. ${ }^{12}$

Ostensibly, the CSP is meant to ensure greater transparency and accountability. Among its many provisions, the CSP requires charities, and societies to provide annual statements of their accounts and activities, to submit to annual audit, and to spend no more than 30 percent of their budgets on administrative costs. ${ }^{13}$ However, the $70 / 30$ rule as it is known is vaguely defined and has been broadly interpreted to include program staff salaries and benefits, training and consultancy services, monitoring and evaluation, and transportation. The rule has led civil society organizations to cut salaries and staff, to restructure, to spend less on monitoring and evaluation,

(2015)

${ }^{1}$ Association For Human Rights In Ethiopia, Ailing Civic Space in an Authoritarian State: The State of Human Rights Defenders and Cost of Dissent in Ethiopia 25-26 (January 2018)

2 Amnesty International, Public Statement, “' Ethiopia: 25 Years of Human Rights Violations”’ JUNE 2016

${ }^{3}$ Ibid

${ }^{4}$ Ethio-Trial Tracker, https://ethiotrialtracker.org/latest-vital-information-on-ethiopians-charged-with-terrorism/

5 Zelalem Kibret, The Terrorism of 'Counterterrorism': The Use and Abuse of Antiterrorism Law, the Case of Ethiopia, European Scientific Journal 521-529 (May 2017)

${ }^{6}$ Ibid

7 Federal Democratic Republic of Ethiopia Constitution, (1995). Negarit Gazeta, 1st Year Number.1, 1995.

${ }^{8}$ Ibid

${ }^{9}$ Tracy J. Ross, A Test of Democracy: Ethiopia's Mass Media and Freedom of Information Proclamation, 114 PENN ST. L. REV. 1047, 1048-57 (2010)

${ }^{10}$ Human Rights Watch, One Hundred Ways Of Putting Pressure - Violations Of Freedom Of Expression And Association In Ethiopia (March 2010)

${ }^{11}$ Jon Abbink, A Decade Of Ethiopia: Politics, Economy And Society 2004-2016 209-211 (2017).

${ }^{12}$ Charities and Societies Proclamation, No. 621/2009, Http://Www.Refworld.Org/Docid/4ba7a0cb2.Html.

${ }^{13} \mathrm{Ibid}$ 
and to take other steps that risk compromising the quality of their work. ${ }^{1}$

The CSP also restricts the types of organizations allowed to work on human rights and governance issues. Only Ethiopian charities and societies may advance or promote: human and democratic rights; equality of nations, nationalities, peoples, religion, or gender; the rights of children and the disabled; conflict resolution and reconciliation; and the efficiency of justice and law enforcement services. ${ }^{2}$ The CSP defines Ethiopian charities and societies as organizations formed under Ethiopian law, fully controlled by Ethiopian nationals, and primarily funded from domestic sources - not more than 10 percent of funds can come from abroad. ${ }^{3}$ Following enactment, the government froze 90 percent of funds belonging to prominent local human rights organizations. ${ }^{4}$

Moreover, the CSP has forced foreign NGOs like Amnesty International and Human Rights Watch to cease human rights advocacy from inside Ethiopia. The government has argued that these restrictions prevent undue foreign influence in Ethiopia's domestic affairs. ${ }^{5}$ However, the CSP has been widely criticized for violating freedom of association and for unnecessarily impeding civil society, and is regarded as a thinly veiled effort to silence critics. ${ }^{6}$ Indeed, because of limited domestic funding sources, the CSP has forced many organizations to close their doors, to restructure, or to rebrand and work on development or other issues not reserved for Ethiopian charities and societies. According to one source, the CSP has eliminated $90 \%$ of local human rights organizations, ${ }^{7}$ and the most prominent organizations that do remain have been forced to reduce capacity by as much as $85 \%{ }^{8}$

Ethiopian civil society's engagement with human rights is shackled by the Charities and Societies Proclamation 621/09, which violates Ethiopia's Constitution and the country's international human rights obligations and commitments. ${ }^{9}$ The law places funding and other restrictions on human rights organizations, and to violate it is a criminal offense. Since 2011, the law has been used to freeze assets of more than one million US dollars belonging to the country's two leading human rights organizations: the Human Rights Council and the Ethiopian Women Lawyers Association. This law has also had a devastating impact on the staff of human rights organizations, the human rights defenders themselves. ${ }^{10}$ For many years human rights defenders have operated in a climate of fear in Ethiopia, subjected to regular harassment, arrest, detention and even violent attack. The underlying impact of the Charities and Societies Proclamation has been to entrench still further, and even to institutionalize, this fear pervading the work of human rights defenders.

\section{Conclusion}

The main intention of the paper was to examine the situation of political security and legal instruments for political insecurity in Ethiopia.eventhough the constitution recognition prevail about human right and democratic right, the practice is viewed as reciprocal ways with the constitutionally degreed rights.

The situation of political security in the last two decades is highly challenged by the political figures, security and police forces through different practice that insecure the politics of the state. The main situation of the political security found in Ethiopia with the condition of political repression, torture and ill-treatment, arbitrary arrest and detention, and enforced to disappearance.

When the situation of political security viewed in Ethiopian, anyone can perceive that the main role of the Ethiopian government with the last two decades was to insecure the political security of the citizens and with its return to maintain and continuing the political power of the TPLF /EPRDF.The main human right which clearly declared in the FDRE (1995) constitution were highly rythorical and attention was given for the party politics than constitutional powers and rights of the citizen.

Though some hopes shown with in transitions time with the present political reform of Ethiopian, the reform should mainly focus on the political security of the citizen, and it must depend on different laws the constitution in line with this, the security sectors, political and justice institutions should stand for political security of the state.

\footnotetext{
${ }^{1}$ Berhanu Denu and Ato G. Zewdie, Impact of the Guideline to Determine Charities' and Societies' Operational and Administrative Costs (70/30 Guideline) - Phase III, Development Assistance Group Ethiopia, 17-18 (September 19, 2013)

${ }^{2}$ Charities And Societies Proclamation, No. 621/2009, http://www.refworld.org/docid/4ba7a0cb2.html.

${ }^{3}$ Ibid

${ }^{4}$ Sisay Alemahu Yeshanew, The Ethiopian Law Governing Civil Society Organizations: Divorcing human rights and development?, HUMAN Rights And Development In The New Millennium: Towards A Theory Of Change 259 (2014)

${ }^{5}$ Saskia Brechenmacher, Civil Society Under Assault: Repression and Response in Russia, Egypt, and Ethiopia, Carnegie Endowment For International Peace 68-69 (May 18, 2017),

${ }^{6}$ Kendra E. Dupuy, Et Al., Who Survived? Ethiopia's Regulatory Crackdown On Foreign-Funded NGOs, Review of International Political

Economy , 22(2), 425 (2015)

${ }^{7}$ Amnesty International, Stifling Human Rights Work: The Impact Of Civil Society Legislation In Ethiopia 24-26 (March 12, 2012

${ }^{8}$ Ibid

${ }^{9}$ Amnesty international ,2014, Sweeping Repression in the Oromia Region Of Ethiopia

${ }^{10}$ Amnesty International, Public Statement, “' Ethiopia: 25 Years of Human Rights Violations’’ JUNE 2016
} 


\section{Reference}

Amnesty international report, 2014, Sweeping Repression in the Oromia Region of Ethiopia

Amnesty international report 2017/2018, the State of the World's Human Rights

Amnesty international report, 2014/2015, The State of The World's Human Rights

Amnesty International, Public Statement, " Ethiopia: 25 Years of Human Rights Violations"' JUNE 2016

Amnesty International, Stifling Human Rights Work: The Impact of Civil Society Legislation in Ethiopia 24-26 (March 12, 2012

Association for Human Rights in Ethiopia, 2016, addressing the escalating human rights crisis in Ethiopia, Geneva

Association for Human Rights in Ethiopia, Ailing Civic Space in an Authoritarian State: The State of Human Rights, Defenders and Cost of Dissent in Ethiopia 25-26 (January 2018)

Berhanu Denu and G. Zewdie, Impact of the Guideline to Determine Charities' and Societies' Operational and Administrative Costs (70/30 Guideline) - Phase III, Development Assistance Group Ethiopia, 17-18 (September 19, 2013)

Center for International Human Rights Law \& Advocacy, 2018, Divide, Develop, and Rule: Human Rights Violations in Ethiopia, University of Wyoming College Of Law

Country Reports on Human Rights Practices for 2016, United States Department of State ,Bureau of Democracy, Human Rights and Labor.

Declaration on the Protection of All Persons from Enforced Disappearance adopted by the General Assembly of the United Nations in its resolution 47/133 of 18 December 1992,

Ethio-Trial Tracker, https:/ethiotrialtracker.org/latest-vital-information-on-ethiopians-charged-with-terrorism/.

European Parliament, Resolution on the Situation in Ethiopia (January 21, 2016), 2016/2520(RSP),

FDRE. (2011), Criminal Justice Policy, Addis Abeba

$\begin{array}{llllll}\text { FDRE. } & \text { Anti-Terrorism } & \text { Proclamation } & 652 / 2009 & \text { (July } & 7,\end{array}$ html.http://www.un.org/en/sc/ctc/specialmeetings/2012/docs/United Nations Security Council Resolution 1373 (2001).pdf (directing States to take measure to prevent and punish terrorism).

Federal Democratic Republic of Ethiopia Constitution, (1995). Negarit Gazeta, 1st Year Number.1, 1995.

Haq, Mahbub ul (1995). Reflections on Human Development. p.115

Http// www.chilot. Ethiopian constitution of 1931, Addis Abeba 16. July

$\mathrm{Http} / /$ definition .us legal .com/political repression. Retrieved on February 18, 2019

Human right watch, 2013, torture and ill treatment in Ethiopia's Maikelawi police station

Human Right watch, 2018, Torture and other Abuses in Jail Ogaden, Somali Regional State, Ethiopia

Human Rights Watch, Analysis of Ethiopia's Draft Anti-Terrorism Law (June 30, 2009)

Human Rights Watch, One Hundred Ways of Putting Pressure - Violations of Freedom Of Expression and Association in Ethiopia (March 2010)

International Covenant on Civil and Political Rights. Adopted by the General Assembly of the United Nations on 19 December 1966

Jennifer Leaning, M.D., S.M.H. Sam Arie, M.Sc. 2001 Human Security: A Framework for Assessment in Conflict and Transition Working Paper Series Volume 11 Number 8 September

Jon Abbink, a Decade of Ethiopia: Politics, Economy and Society 2004-2016 209-211 (2017). FDRE, Charities and Societies Proclamation, No. 621/2009, Addis Abeba

Kendra E. Dupuy, Et Al., Who Survived? Ethiopia's Regulatory Crackdown On Foreign-Funded NGOs, Review of International Political Economy, 22(2), 425 (2015),

Mengesha, Silencing Dissent, 27 JouRNAL of DEMOCRACY 93 (2016)

Michael G. Smith and Jacqueline Whelan, 2008 Advancing Human Security: New Strategic Thinking for Australia, Security Challenges, Vol. 4, No. 2.pp. 1-22

Oz Hassan. (2015), Political security: from the 1990s to the Arab Spring, Contemporary Politics, 21:1, and 8699

Ramshe Thaker, 2011,the United Nations and human security ,Canadian Foreign policy Journal

Revised Constitution of the Empire of Ethiopia, Proclamation No. 149 of 1955.

Sadako Ogata and Johan Cels, Human Security_-Protecting and Empowering the People, Global Governance Vol. 9, No. 3 (July-Sept. 2003), pp. 273-282

Saskia Brechenmacher, Civil Society Under Assault: Repression and Response in Russia, Egypt, and Ethiopia, Carnegie Endowment For International Peace 68-69 (May 18, 2017),

Sisay Alemahu Yeshanew, the Ethiopian Law Governing Civil Society Organizations: Divorcing human rights and development? Human Rights and Development in the New Millennium: Towards A Theory of Change 259 (2014)

Thakur, Ramesh (1997). 'From National to Human Security' Asia Pacific Security: The Economics-Politics Nexus. 
The constitution of the peopl's Democratic Republic of Ethiopia, (1987),Negarit Gazetta,vol.47.no. 1,Addis Abeba,,12.September

The Oakland Institute and the Environmental Defender Law Center, Ethiopia's Anti-Terrorism Law: A Tool to Stifle Dissent 14-17 (2015)

Tracy J. Ross, A Test of Democracy: Ethiopia's Mass Media and Freedom of Information Proclamation, 114 PENN ST. L. REV. 1047, 1048-57 (2010)

UN Universal Periodic Review (UPR) consideration of Ethiopia's human rights performance from 2009-14

UNDP, 1994, human development report, New York Oxford, Oxford University Press

United nation trust fund for human security, 2009, Human Security in Theory and Practice, United Nations, USA United Nation Trust Fund for Human Security, 2016, human security hand book

United States Department of State Country Reports on Human Rights Practices for 2015.Bureau of Democracy, Human Rights and Labor

United States Department of State Country Reports on Human Rights Practices for 2016, Bureau of Democracy, Human Rights and Labor

Venu Menon, Sudha, 2007, Human security: Concept and practice, ICFAI Business School, 31 March

Zelalem Kibret, the Terrorism of 'Counterterrorism': The Use and Abuse of Antiterrorism Law, the Case of Ethiopia, European Scientific Journal 521-529 (May 2017) 